\title{
Results of Hemodynamic Correction in Patients with Double Outlet Right Ventricle
}

\author{
Abralov Kh. K. ${ }^{1}$, Karimov O. Kh. ${ }^{1}$, Siromakha S. O. ${ }^{2}$, Dziuriy I. V. ${ }^{2}$, Truba Ya. P. ${ }^{2}$, Lazorishinets V. V. ${ }^{2}$ \\ ${ }^{1}$ Republic Specialized Scientific Practical Medical Center of Surgery named after V. Vakhidov, Tashkent, Uzbekistan \\ ${ }^{2}$ National M. M. Amosov Institute of Cardiovascular Surgery National Academy of Medical Sciences of Ukraine, \\ Kyiv, Ukraine
}

\begin{abstract}
Aim. To analyze results of hemodynamic correction in surgical treatment of double outlet right ventricle (DORV).

Materials and methods. For the period from January 1996 to September 2017, 31 (6.03\% of total number of patients with DORV) patients underwent hemodynamic correction of DORV. The age of the patients ranged from 1 to 19 years $(71.2 \pm 50.5$ months on the average). The weight of the patients ranged from 9 to $41 \mathrm{~kg}(19.6 \pm 11.3 \mathrm{~kg}$ on the average). Of these, 19 (61.3\%) were male patients and $12(38.7 \%)$ were female patients. The overwhelming majority $(25(80.6 \%)$ ) of the patients were diagnosed with transposition-type DORV. The anatomy of DORV with non-committed ventricular septal defect was observed in $5(16.1 \%)$ patients. In one patient $(3.1 \%)$, the anatomy of DORV (in the form of tetralogy of Fallot) was combined with tricuspid valve atresia.

Results. The main reasons of hemodynamic correction in 16 (51.6 \%) cases was LV hypoplasia. In 2 cases it was combined with tricuspid valve (TV) straddling, and in 2 cases it was an integral part of the unbalanced form of complete atrio-ventricular communication (AVC). In one case (3.1\%), the unbalanced form of complete AVC was combined with a mixed form of the common ventricle. The mixed form of the common ventricle was the reason of hemodynamic correction in $9(29 \%)$ patients. In $2(6.2 \%)$ cases, hemodynamic correction was performed due to the anatomy of the RV hypoplasia. In the remaining 2 patients, anatomy of the common ventricle was not diagnosed, but a combination of other concomitant defects was a contraindication to biventricular correction. Palliative operations (Blalock-Taussig shunt, BTS) as the first stage of correction were performed in 16 (51.6\%) patients. In 2 patients with LV outflow tract obstruction, systemic-pulmonary anastomosis was applied in combination with plastic repair of the great vessel roots using the proprietary technique for elimination of the left ventricular outflow tract (LVOT) stenosis. Bidirectional cavopulmonary anastomosis (BCPA) was applied in $29(93.5 \%)$ cases. Of these, $4(13.8 \%)$ patients subsequently underwent total cavopulmonary anastomosis (TCPA) procedure. Two patients with good hemodynamic parameters underwent TCPA without prior palliative procedures.

Conclusion. Palliative surgery as the first stage to hemodynamic correction is accompanied by significant improvement in hemodynamic parameters of patients. Application of BCPA as the second stage of hemodynamic correction provides good results and is required to prepare the patient for TCPA. The long-term period is characterized by improvement in the quality of life in patients with complex DORV. In the long-term period, $85.2 \%$ of patients are classified as NYHA FC I.
\end{abstract}

Keywords: congenital heart disease, double outlet right ventricle, echocardiography, diagnosis, pediatric surgery.

Double outlet right ventricle (DORV) is a complex congenital heart defect characterized by disorder of ventriculo-arterial connection, where the two great arteries either completely or preferentially originate from the right ventricle [1]. Development of the disorder of ventriculo-arterial connection is often accompanied by disorder of atrioventricular connection and development of a number of concomitant heart defects [2], the most threatening of which lead to hemodynamics of univentricular heart (UVH) [3]. Considering the fact that with this state of hemodynamics one ventricle of the heart becomes its main "pump", first Glenn (in the 1960s) [4], and then Fontan and Baudet, who amplified his idea while developing an option for correction, noted the importance of the "primum non nocere" principle ("first, to do no harm" in Latin) and introduced the principle of the "passive pulmonary blood flow" using anastomoses between vena cava and pulmonary artery [5]. The use of this principle made it possible to avoid myocardial damage, while maintaining systolic and diastolic functions, integrity of the valve function and electrophysiology of the heart. The principle of the proposed hemodynamic correction has been significantly improved over the last decade, and it is now applied not only in case of single-ventricular hemodynamics, but in some cases as part of "anatomical" correction of other complex congenital heart defects [6]. Having extensive experience in the correction of complex 
DORV variants, in this study we would like to report our results of hemodynamic correction in surgical treatment of double outlet right ventricle.

Material and methods. For the period from January 1996 to September 2017, 530 patients underwent surgical treatment of DORV at the Cardiovascular Surgery Institute of the Academy of Medical Sciences of Ukraine and the Republican Specialized Center for Surgery named after Academician V.V. Vakhidov. Of these, 31 (6.03\%) patients underwent hemodynamic correction of the defect. The age of the patients ranged from 1 to 19 years $(71.2 \pm$ 50.5 months on the average). The weight of the patients ranged from 9 to $41 \mathrm{~kg}(19.6 \pm 11.3 \mathrm{~kg}$ on the average $)$. Of these, $19(61.3 \%)$ were male patients and $12(38.7 \%)$ were female patients. The general condition of the patients on admission was assessed according to the NYHA classification. Thirteen $(37.1 \%)$ patients were classified as NYHA Class II and 19 (62.9\%) patients were classified as NYHA Class III. In determining the defect, the generally accepted " $50 \%$ rule" was used (1). The diagnosis was established and the anatomical features of the defect were determined based on comparison of data from 2-dimensional echocardiography (Toshiba Aloka 380 scanner), angiocardiography (Siemens-Elema apparatus), and data obtained intraoperatively. The overwhelming majority (25 (80.6 $\%)$ ) of the patients were diagnosed with transposition-type DORV. The anatomy of DORV with non-committed ventricular septal defect was observed in $5(16.1 \%)$ patients. In one patient $(3.1 \%)$, the anatomy of the DORV (by type of tetralogy of Fallot) was combined with tricuspid valve atresia. The main concomitant heart defects are shown in Table 1.

\section{Table 1}

Frequency of concomitant defects

Types of defects DORV (TGA DORV (circulatory

type) failure VSD type)

$\begin{array}{lll} & \mathrm{n}=25 & \mathrm{n}=5\end{array}$

$\begin{array}{lll}17 & 17 & 5 \\ \text { Right ventricle hypoplasia } & 3\end{array}$

Right ventricle hypoplasia $3 \quad-$

Left ventricle hypoplasia $16 \quad 3$

Mixed-type UVH $10 \quad 1$

$\begin{array}{lll}\text { Atrial septal defect } & 17 & 5\end{array}$

Anomalous vena cava

return

AV valve straddling $\quad 4 \quad 1$

\begin{tabular}{lll}
\hline PA atresia & 3 & 1 \\
\hline Atrioventricular & 3 & 2
\end{tabular}

communication

AV valve insufficiency

(grade I-II)

Stenosis and hypoplasia of 2

the LV outflow tract
The function of the left ventricle (LV), AV valve insufficiency and sizes of the branches of the pulmonary artery were evaluated based on the echo data. Subsequently, the echo data were compared with those obtained with angiocardiography which was performed in all patients. The following hemodynamic parameters were determined to decide on the surgical treatment tactics: blood saturation in the arterial bed, Nakata index, pulmonary circulation (PC) pressure, vascular resistance in the $\mathrm{PC}$ and functional cardiac ventricle volume.

In $16(51.6 \%)$ cases, palliative surgery was initially performed: in 13 patients, inter-arterial anastomosis was applied on the right, and 3 patients underwent pulmonary artery banding. Cavopulmonary anastomosis (Glenn procedure) was performed in all the patients at the second stage. In $13(41.9 \%)$ patients, Glenn procedure was performed primarily. Total cavopulmonary anastomosis (Fontan procedure) was applied to $6(19.3 \%)$ patients, and, of these, in 4 patients it was performed as the second stage after bidirectional cavopulmonary anastomosis. In 11 cases, the procedure was performed under conditions of aortic occlusion. In the remaining cases, hemodynamic correction was performed using auxiliary perfusion.

Standard statistical Statgraphics, STATISTICA version 6.0 (Stat Soft Inc. Tulsa, OK, USA) packs were used for statistical data analysis. Microsoft Office 10 pack was used for the initial preparation of tables and intermediate calculations.

Results. DORV is one of the most complex and morphologically diverse congenital heart defects. In some cases, a large variety of concomitant heart defects make it impossible to perform bi-ventricular or radical correction of the defect. According to Anderson R. H. [7], ventricular imbalance is the main indication for a "single ventricular" correction. Its main causes are the presence of double-inflow ventricle, atrioventricular valve straddling, unbalanced atrioventricular septal defect and critical stenosis of the left ventricular outflow tract at the stage of fetal development. This combination, according to Olivier Villemain et al. [8], is commonly observed in patients with DORV with uncommitted VSD. In our study, the proportion of patients with anatomy of the "common ventricle" and DORV with uncommitted VSD was $16.1 \%$ (5 of 31 patients). Among the patients with DORV with transposition this was $13.7 \%$ (22 of 159 patients). The main reasons for hemodynamic correction are shown in Table 1. Thus, in 16 (51.6 \%) cases, hemodynamic correction was reasoned by LV hypoplasia. In 2 cases, it was combined with the tricuspid valve (TV) straddling, and in 2 cases it was an integral part of the unbalanced form of complete atrio-ventricular communication (AVC). In one case (3.1\%), the unbalanced form of complete AVC was combined with a mixed form of the common ventricle. The mixed form of the common ventricle was the reason for hemodynamic correction in $9(29 \%)$ patients. In $2(6.2 \%)$ cases, hemodynamic correction was performed due to the 
Table 2

Demographic and hemodynamic parameters of patients before and after BTS

\begin{tabular}{lccc} 
Parameter & $\begin{array}{c}\text { Before BTS } \\
(\mathbf{n = 1 2})\end{array}$ & $\begin{array}{c}\text { Before Glenn } \\
\text { procedure } \\
(\mathbf{n = 1 2 )}\end{array}$ & P value \\
\hline Age (months) & $18.2 \pm 11.1$ & $28.9 \pm 9.6$ & $<.0001$ \\
\hline Weight $(\mathrm{kg})$ & $8.6 \pm 2.3$ & $18.6 \pm 6.5$ & $<.0001$ \\
\hline $\mathrm{Hb}(\mathrm{g} / \mathrm{L})$ & $166.9 \pm 33.9$ & $161.6 \pm 25.7$ & $\mathrm{n} / \mathrm{a}$ \\
\hline Saa $\mathrm{O}_{2}(\%)$ & $77.0 \pm 12.1$ & $81 \pm 10.05$ & $<.05$ \\
\hline LV EDI $\left(\mathrm{ml} / \mathrm{m}^{2}\right)$ & $21.1 \pm 3.1$ & $22.9 \pm 1.8$ & $\mathrm{n} / \mathrm{a}$ \\
\hline LVEF $(\%)$ & $66 \pm 10.1$ & $68.7 \pm 9.4$ & $\mathrm{n} / \mathrm{a}$ \\
\hline PA diameter $(\mathrm{mm})$ & $6.2 \pm 1.4$ & $8.7 \pm 2.5$ & $<.0001$ \\
\hline RPA diameter $(\mathrm{mm})$ & $5.02 \pm 1.28$ & $7.3 \pm 2.7$ & $<.05$ \\
\hline LPA diameter $(\mathrm{mm})$ & $5.9 \pm 1.6$ & $7.7 \pm 2.3$ & $<.001$ \\
\hline $\begin{array}{l}\text { Nakata index } \\
\left.\text { (mm }{ }^{2} / \mathrm{m}^{2}\right)\end{array}$ & $142.08 \pm 68.2$ & $261.5 \pm 100.2$ & $<.0001$ \\
\hline $\begin{array}{l}\text { Presence of volume } \\
\text { of plasma circulation } \\
\text { (VPC) }(\%)\end{array}$ & $5(45.8 \%)$ & - & $<.0001$ \\
\hline
\end{tabular}

anatomy of the RV hypoplasia. In the remaining 2 patients, the anatomy of the common ventricle was not diagnosed, but a combination of other concomitant defects was a contraindication to biventricular correction. One of these patients aged 4 was diagnosed with DORV with transposition combined with PA stenosis and profound coronary arteries in the right ventricle outflow tract. Another patient was also diagnosed with DORV with transposition and LA stenosis but combined with severe LV fibroelastosis, which resulted in reduced LV ejection fraction up to $36 \%$, followed by the increase up to $54 \%$ after hemodynamic correction (bi-directional cavopulmonary anastomosis (BCPA)).
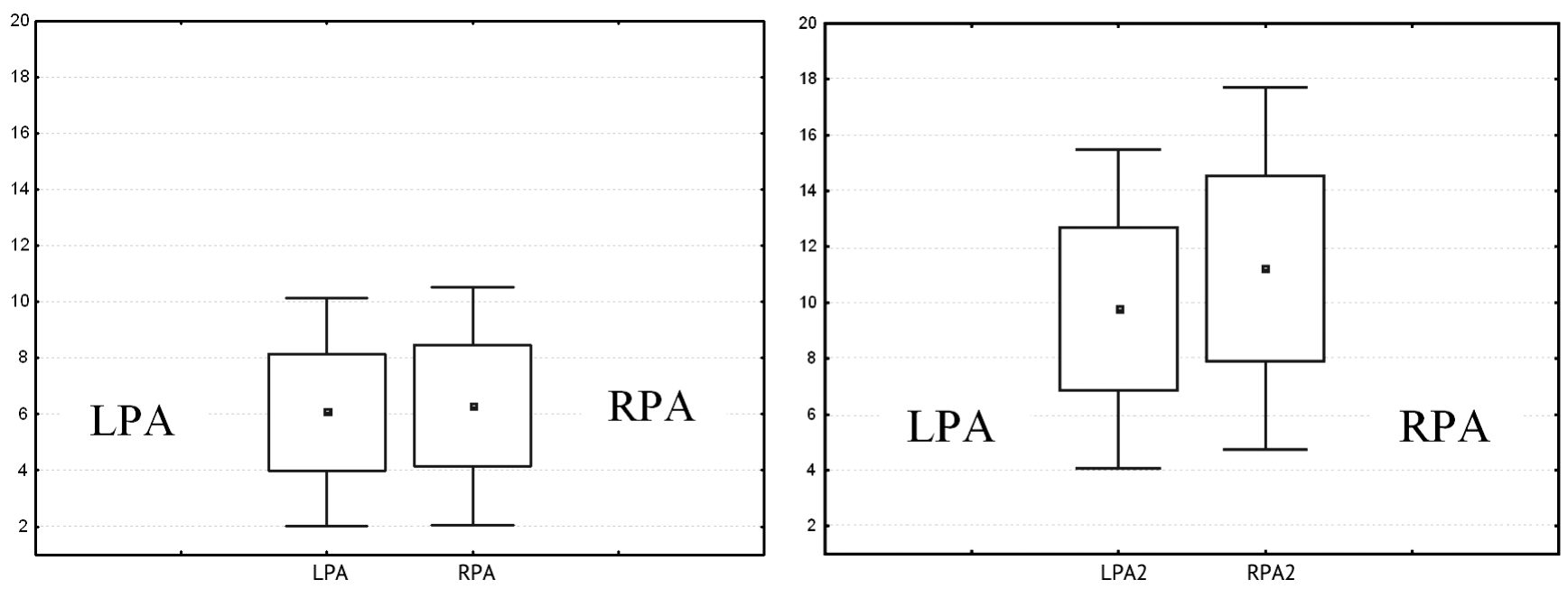

Fig. 1. Distribution of the average values of the diameters of PA branches after the application of BTS on the right side
Hemodynamic correction was first proposed as early as in the 1960s [4], but the real heyday of "hemodynamic procedures" began in the 2000s. They took a rightful place in the correction protocols of many congenital heart defects.

The most common staged "hemodynamic correction" consists of three steps:

1. Palliative surgery. If pulmonary blood flow is poor, systemic pulmonary anastomosis is applied. If signs of high pulmonary hypertension are present, PA banding is preferred.

2. The second stage is the "classic incomplete Fontan" procedure, classic Glenn procedure, or application of bidirectional cavopulmonary anastomosis. All of them are intermediate to the third stage.

3. The third stage is application of total cavopulmonary anastomosis (TCPA), or the classic Fontan procedure [10].

Palliative procedures as the first stage of correction were performed in 16 (51.6\%) patients. Application of BlalockTaussig shunt (BTS) in 13 (41.9\%) cases was mainly due to hypoplasia of the pulmonary artery branches and early age of the patient in combination with severe hemodynamic abnormalities (severe hypoxemia and anoxic blue spells (ABS)). Table 2 shows hemodynamic parameters of patients before and after BTS application.

As may be seen from the Table, palliative procedures as the first stage of hemodynamic correction seem to be effective. There is significant improvement in hemodynamic parameters (Nakata index and LA branch diameter) and the patient's condition. However, in this category of patients, the procedure does not improve the functional ventricle volume (LV in all patients). Aorto-pulmonary anastomosis was applied to all the patients on the right side, which affected the diameter of the pulmonary artery on the right (see Fig. 1).

In 2 patients with the LV outflow tract obstruction, systemic-pulmonary anastomosis was applied in combination 


\section{Table 3}

Demographic and hemodynamic parameters of patients before hemodynamic correction

\begin{tabular}{|c|c|c|c|}
\hline Parameter & $\begin{array}{l}\text { Before cor- } \\
\text { rection } \\
(n=31)\end{array}$ & $\begin{array}{c}\text { After correc- } \\
\text { tion } \\
(n=27)\end{array}$ & $P$ value \\
\hline Age (months) & $71.2 \pm 50.5$ & $169.5 \pm 103.4$ & $<.0001$ \\
\hline Height (kg ) & $19.6 \pm 11.3$ & $38.2 \pm 12.5$ & $<.0001$ \\
\hline $\mathrm{Hb}(\mathrm{g} / \mathrm{l})$ & $163.9 \pm 13.7$ & $134.2 \pm 11.7$ & $<.05$ \\
\hline $\mathrm{Sa}_{2} \mathrm{O}_{2}(\%)$ & $78 \pm 10.05$ & $86 \pm 10.05$ & $<.05$ \\
\hline CV EDI $\left(\mathrm{ml} / \mathrm{m}^{2}\right)$ & $65.4 \pm 10.7$ & $51.2 \pm 7.2$ & $<.001$ \\
\hline CVEF (\%) & $55 \pm 4.1$ & $53.7 \pm 3.4$ & $\mathrm{n} / \mathrm{a}$ \\
\hline Nakata index $\left(\mathrm{mm}^{2} / \mathrm{m}^{2}\right)$ & $234.5 \pm 52.2$ & $230.5 \pm 48.3$ & $\mathrm{n} / \mathrm{a}$ \\
\hline $\begin{array}{l}\text { Average pressure in PA } \\
(\mathrm{mmHg})\end{array}$ & $13 \pm 6.7$ & $12.6 \pm 4.3$ & $\mathrm{n} / \mathrm{a}$ \\
\hline $\begin{array}{l}\text { PA resistance (Wood } \\
\text { unit) }\end{array}$ & $1.4 \pm 0.8$ & - & - \\
\hline $\begin{array}{l}\text { Patient functional } \\
\text { status (NYHA) }\end{array}$ & $\begin{array}{l}\text { II (18 (58 \%)) } \\
\text { I (13 (42\%)) }\end{array}$ & $\begin{array}{l}\text { II (3 (11.1 \%)) } \\
\text { I (24 (88.9\%)) }\end{array}$ & $\begin{array}{l}<.001 \\
<.001\end{array}$ \\
\hline
\end{tabular}

with plastic repair of the great vessel roots using the proprietary technique for elimination of the LVOT stenosis. In 3 cases, the pulmonary artery banding and atrioseptotomy were performed in patients with the anatomy of the common ventricle and DORV with transposition combined with high pulmonary hypertension. These procedures were performed in the early period after the birth of patients and diagnosing them with this heart defect (in all patients before the age of 1 month). This allowed to provide the second stage of correction in these patients. A bidirectional cavopulmonary anastomosis was applied to all patients during the period of $15 \pm 3.4$ months after the PA banding.

In our cohort of patients, bidirectional cavopulmonary anastomosis was applied in $29(93.5 \%)$ cases. Of these, 4 (13.8\%) patients subsequently underwent total cavopulmonary anastomosis (TCPA). TCPA was applied without prior palliative procedures in two patients with good hemodynamic parameters. Table 3 shows some demographic and hemodynamic parameters.

The decision to apply BCPA was made if the following criteria were met:

1. Favorable anatomy of the branches of the pulmonary artery (Nakata index $\geq 250 \mathrm{~mm} / \mathrm{m}^{2}$ ).

2. Low resistance of the vascular bed of the pulmonary circulation (Wood unit $\leq 2$ ).

3 . The patient was over 1 year of age.

4. Insufficiency of the AV valves of mild or moderate degree (I or II degree according to echo and ACG).

Total cavopulmonary anastomosis was indicated in cases when the following criteria were met:

1. Favorable anatomy of the branches of the pulmonary artery (Nakata index $\geq 250 \mathrm{~mm} / \mathrm{m}^{2}$ ).
2. Low resistance of the vascular bed of the pulmonary circulation (Wood unit $\leq 2$ ).

3. The patient was over 4 year of age.

4. Absence of insufficiency of AV valves.

5. Absence of anomalies of the vena cava return.

6. Satisfactory function of the "common ventricle".

Surgical treatment was performed in the overwhelming majority $(24(68.5 \%))$ of cases under conditions of auxiliary perfusion. In $11(31.5 \%)$ cases, the surgery was performed under conditions of aortic occlusion. In 6 cases, when TCPA was applied, and in 5 cases, when BCPA was applied, the aortic occlusion was caused by the operative exploration of the heart anatomy and formation of intra-atrial tunnel in the case of the Fontan procedure. In 5 cases of BCPA application, the pulsatile flow was left in the PC. According to Tjark Ebels et al. [9], this tactic is more physiological, it prevents the development of intrapulmonary shunts and allows patients to survive the postoperative period more easily. Unfortunately, we cannot confirm or deny this statement due to few similar cases, but there is an ongoing study in this field.

In all cases of TCPA application, the classical scheme of intra-atrial tunneling was used with fenestration remained. According to the data from many researchers [10], fenestration make it possible to avoid lymphorrhea development in the early postoperative period, as well as such complications as atrial arrhythmias in the late period.

The duration of stay in the ICU was on average $5.1 \pm$ 3.9 days. The early postoperative course in $25(71.4 \%)$ patients proceeded with class I heart failure, and in $3(7.6 \%)$ cases it proceeded with class II heart failure. Acute heart failure was observed in 6 patients. There was an acute cerebrovascular accident in one patient 2 weeks after the correction. In the early postoperative period, mortality rate was $8.5 \%$ ( 3 cases per 35 corrections): 2 cases after BCPA and 1 case after TCPA. In one case, the patient was admitted to life-saving surgery after IAA thrombosis; it was decided to perform BCPA, although there was still hypoplasia of the PA branches. Subsequently, this reason led to the development of cavopulmonary anastomosis in this patient. In the other case, the patient died due to circular myocardial infarction. In the third case, after initial application of total cavopulmonary anastomosis, development of heart failure was observed in the patient in early postoperative period. The attempt to perform reverse anastomosis failed. Postmortem examination showed the development of sclerosis in the vessels of the pulmonary circulation.

The long-term follow-up included $27(84.6 \%)$ of the 28 survived patients. The average duration of follow-up was $36.4 \pm 12.2$ months ( 24 to 50 months). Condition of all patients was satisfactory. Twenty three $(85.2 \%)$ patients were classified as NYHA FC I, and 4 (14.8\%) patients were classified as NYHA FC II. As may be seen from Table 3, the patients' condition improved significantly after hemodynamic correction of the defect. However, it should be noted that after the application of total cavopulmonary anastomosis the 
volume of the functioning ventricle also reliably decreased. This suggests that it is impossible to return to biventricular correction in the future in these cases, and these patients are candidates for cardiac transplantation.

\section{Conclusions}

1. The complex anatomy of DORV combined with such concomitant heart defects as hypoplasia of one of the heart ventricles, complete atrioventricular communication, atrioventricular valve straddling makes it impossible to perform biventricular correction (31 $(6.03 \%)$ of the total number of patients with DORV).

2. Palliative surgery as the first stage of hemodynamic correction is accompanied by significant improvement in hemodynamic parameters in the patients.

3. BCPA application as the second stage of hemodynamic correction provides good results and is required to prepare the patient for TCPA.

4. The long-term period is characterized by improvement in the quality of life of patients with complex DORV form. In the long-term period, $85.2 \%$ of patients were classified as NYHA FC I.

5. It is necessary to continue research as we gain experience of hemodynamic correction in patients with DORV.

\section{References}

1. Kirklin JW, Barratt-Boyes BG. Double-outlet right ventricle. In: Kirklin JW, Barratt-Boyes BG, editors. Cardiac surgery. 3rd ed. New York: Churchill Livingston; 2007. p. 1469-500.

2. Tchervenkov C, Walters HL 3rd, Chu VF. Congenital Heart Surgery Nomenclature and Database Project: Double outlet left ventricle. Ann Thorac Surg. 2000 Apr;69(4 Suppl):S264-9.

3. Anderson RH, Cook AC. Morphology of the functionally univentricular heart. Cardiol Young 2004;14(Suppl. 1):312.

4. Trusler GA, MacGregor D, Mustard WT. Cavopulmonary anastomosis for cyanotic congenital heart disease. J Thorac Cardiovasc Surg. 1971;62:803-9.

5. Fontan F, Baudet E. Surgical repair of tricuspid atresia. Thorax. 1971;26:240-8. https://doi.org/10.1136/ thx.26.3.240

6. Yie K, Sung S, Kim D, Woo J. Bidirectional cavopulmonary shunt as a rescue procedure for right ventricular endomyocardial fibrosis. Interact Cardiovasc Thorac Surg. 2004 Mar;3(1):86-8. https://doi.org/10.1016/S15699293(03)00189-0

7. Anderson RH, Ho SY. Which hearts are unsuitable for biventricular correction? Ann Thorac Surg 1998;66(2):6216.

8. Villemain O, Bonnet D, Houyel L, Vergnat M, Ladouceur M, Lambert V, et al. Double-Outlet Right Ventricle With Noncommitted Ventricular Septal Defect and 2 Adequate Ventricles: Is Anatomical Repair Advantageous? Semin Thorac Cardiovasc Surg. Spring 2016;28(1):69-77. https:// doi.org/10.1053/j.semtcvs.2016.01.007

9. Tjark Ebels. Double-outlet right ventricle univentricular repaire. EACTS/ESTS joint meeting. Postgraduate courses; 2001 Sept 16-19; Lisbon. p. 61-3.

10. Jaquiss R, Imamura M. Single ventricle physiology: surgical options, indications and outcomes. Curr Opin Cardiol. 2009 Mar;24(2):113-8. https://doi.org/10.1097/ HCO.0b013e328323d85a

\section{Результати гемодинамічної корекції подвійного відходження магістральних судин від правого шлуночка}

Абралов Х. К. ${ }^{1}$, Карімов О. Х. ${ }^{1}$, Сіромаха С. О. ${ }^{2}$, Дзюрій І. В. ${ }^{2}$, Труба Я. П. ${ }^{2}$, Лазоришинець В. В. ${ }^{2}$

${ }^{1}$ ДУ «Республіканський спеціалізований науково-практичний медичний центр хірургії імені академіка В. Вахідова», м. Ташкент, Узбекистан

${ }^{2}$ ДУ «Національний інститут серцево-судинної хірургії імені М. М. Амосова НАМН України», м. Київ, Україна

\section{Резюме}

Мета дослідження. Оцінити результати застосування гемодинамічної корекції в хірургічному лікуванні подвійного відходження магістральних судин (ПВМС) від правого шлуночка (ПШ).

Матеріали і методи. За період із січня 1996 по вересень 2017 року в НІССХ імені М. М. Амосова НАМН України і РСЦХ імені академіка В. Вахідова 31 (6,03 \%) пацієнту з приводу ПВМС від ПШ виконували гемодинамічну корекцію вади. Вік пацієнтів коливався від 1 до 19 років (у середньому 71,2 \pm 50,5 міс.). Вага хворих - від 9 до 41 кг (у середньому 19,6 $\pm 11,3$ кг). 3 них 19 (61,3\%) пацієнтів були чоловічої та 12 (38,7 \%) жіночої статі. У переважної більшості (25 (80,6 \%) пацієнтів) діагностовано транспозиційний тип ПВМС від ПШ. У 5 (16,1 \%) - спостерігалася анатомія ПВМС від ПШ з некомітуючим дефектом міжшлуночкової перегородки. В 1 випадку (3,1\%) анатомія тетрадного варіанта ПВМС від ПШ поєднувалася з атрезією трикуспідального клапана.

Результати та обговорення. Основні показання до гемодинамічної корекції наведені в таблиці 1. Так, у $16(51,6 \%)$ випадках показанням до гемодинамічної корекції стала гіпоплазія лівого шлуночка (ЛШ). У 2 випадках вона поєднувалася зі страдлінгом трикуспідального клапана (ТК), а у 2 випадках - була складовою частиною незбалансованої форми повної атріовентрикулярної комунікації (АВК). В 1 випадку (3,1 \%) незбалансована форма повної АВК поєднувалася зі змішаною формою загального шлуночка (ЗШ). Змішана форма ЗШ була показанням до гемодинамічної корекції в 9 (29 \%) пацієнтів. У 2 (6,2 \%) випадках анатомія гіпоплазії ПШ обумовила гемо- 
динамічну корекцію. Ще в 2 пацієнтів анатомії загального шлуночка не діагностовано, проте поєднання інших супутніх вад стало протипоказанням до двошлуночкової корекції. Паліативні операції як перший етап корекції були проведені у 16 (51,6 \%) пацієнтів.

У 2 випадках у пацієнтів з обструкцією вихідного тракту (ВТ) ЛШ накладення системно-легеневого анастомозу поєднувалося із пластикою кореня магістральних судин за оригінальною методикою для усунення стенозу ВТЛШ. 3 усіх хворих у 29 (93,5 \%) випадках було накладено двонаправлений кавапульмональний анастомоз (ДКПА). 3 них у подальшому 4 (13,8 \%) пацієнтам було накладено тотальний кавапульмональний анастомоз (ТКПА). Двом пацієнтам з добрими гемодинамічними показниками ТКПА було накладено без попередніх паліативних процедур.

Висновки. Паліативні операції як перший етап до гемодинамічної корекції супроводжуються достовірним поліпшенням гемодинамічних показників пацієнтів.

Накладення ДКПА як другого етапу гемодинамичної корекції супроводжується хорошими результатами і $є$ необхідним для підготовки пацієнта до ТКПА.

Віддалений період характеризується поліпшенням якості життя пацієнтів зі складною формою ПВМС від ПШ. У віддалений період 85,2 \% пацієнтів перебувають у функціональному класі I за NYHA.

Ключові слова: вроджена вада серия, подвійне відходження магістральних судин від правого шлуночка, ехокардіографія, діагностика, дитяча хірургія.

Стаття надійшла в редакцію 17.04.2019 р. 